Article

\title{
Too Many Cooks in the Kitchen? The Division of Financing in World Bank Projects and Project Performance
}

\author{
Matthew S. Winters \\ Department of Political Science, University of Illinois, Urbana, IL 61801, USA; E-Mail: mwinters@illinois.edu
}

Submitted: 15 November 2018 | Accepted: 14 January 2019 | Published: 5 June 2019

\begin{abstract}
The total funding envelope for World Bank projects is often divided among various state and non-state actors, each of which can have competing ideas about or interests in the project. How does the division of financing relate to overall project effectiveness? I argue that too many funding streams in a project can reduce project effectiveness by creating delays, increasing transaction costs, and blurring lines of accountability. I combine original data on the number and concentration of financial collaborators in World Bank projects with the World Bank's ratings of project performance, looking at within-country variation across projects to explore whether or not there is evidence of reduced aid effectiveness in projects with more participants. The results suggest that projects with significant cofinancing receive somewhat worse project ratings.
\end{abstract}

\section{Keywords}

aid effectiveness; cofinancing; foreign aid; World Bank

\section{Issue}

This article is part of the issue "Aid Impact and Effectiveness", edited by Rachel M. Gisselquist and Finn Tarp (UNU-WIDER, Finland).

(C) 2019 by UNU-WIDER; licensee Cogitatio (Lisbon, Portugal). This article is licensed under a Creative Commons Attribution 4.0 International License (CC BY).

\section{Introduction}

Major foreign-financed development projects often involve cooperation on the part of multiple actors. Many projects involve initial negotiations between a donor and a national government, followed by donor monitoring of the project's implementation by an agency of the national government, subnational government entities, private contractors, or non-governmental organizations (Winters, 2010). For a given project, there can be multiple implementers, responsible for different project components, and the success of certain components might depend on activities happening in other parts of the project that are administered by different entities. Beyond a single foreign donor and an implementer, cooperation in a development project may include cofinancing by multiple foreign and/or domestic sources. In many cases, the reality of a development project is much more complex that a straightforward principal-agent relationship in which a single foreign donor provides funding to an aid-receiving government for project implementation by a single relevant ministry.
In this paper, I argue that involving more actors in the design and implementation of development projects risks less satisfactory outcomes. Having more actors cooperating in a single development project increases transaction costs, increases the likelihood of implementation delays, and reduces the clarity of lines of accountability within a project. Each of these problems risks undermining development impact.

I explore this hypothesis using outcome ratings produced for World Bank projects by the World Bank's Independent Evaluations Group and data from Winters and Streitfeld (2018) about the division of financing in those projects. I find that the presence of multiple financers correlates with slight decreases in the likelihood of a project receiving a satisfactory rating. This is particularly true for the small number of projects that use funding from non-governmental organizations in the aidreceiving country. Other patterns related to particular types of cofinancers are less robust. 


\section{Project-Level Determinants of Aid Effectiveness}

While the most common approach in the literature to understanding aid effectiveness is to study the macroeconomic impacts of aid on growth (see Qian, 2015, for a recent review), another stream of research studies project-level assessments of development outcomes, trying to understand the characteristics of successful projects and/or the contexts in which development projects are most successful. In some of the earliest entries in this literature, scholars use cross-project data to assess whether or not local participation in development projects improves development outcomes (Finsterbusch \& Van Wicklin, 1987; Isham, Narayan, \& Pritchett, 1995). Other studies focus on how the political or economic characteristics of aid-receiving countries affect project success (Denizer, Kaufmann, \& Kraay, 2013; Dollar \& Levin, 2005; Guillaumont \& Laajaj, 2006; Isham \& Kaufmann, 1999; Isham, Kaufmann, \& Pritchett, 1997), although a key finding of Denizer et al. (2013) is that development project success varies more within countries than it does across countries. Some studies focus on particular actions taken by aid agencies in preparing projects or during their implementation (Deininger, Squire, \& Basu, 1998; Denizer et al., 2013; Kilby, 2000, 2015). Recent work has situated aid agencies within donor governments more broadly and argued that greater aid agency autonomy leads to better development outcomes in challenging contexts (Honig, 2018, in press).

In an article that undertakes an analysis closely related to the one presented here, Shin, Kim and Sohn (2017) analyze the relative performance of World Bank projects implemented by the borrowing government versus those implemented by non-governmental actors or by a combination of governmental and nongovernmental actors. Although the number of World Bank projects implemented by non-governmental actors is small-only 29 out of the 647 projects that they study-they consistently estimate that these projects have better evaluation scores, controlling for the total size and duration of the projects and the country, year, and sector of their implementation. They additionally find that the likelihood of having a positive project evaluation is increasing in the number of non-governmental organizations involved in project implementation: a finding that runs counter to the argument and evidence presented below.

\section{The Challenges of Multiple Principals in Development Projects}

On the one hand, involving multiple actors in development projects suggests the possibility of important benefits. In terms of financing, the involvement of more actors can lead to a greater resource envelope, making it plausible that a development project will be able to do more of what it is supposed to do (e.g., build schools, train bureaucrats, finance microlending). In addition, if the counterfactual scenario to having multiple principals collaborating on a single development project is that the different development industry actors would undertake separate, overlapping projects, then there should be efficiency gains to be made by coordinating aid and avoiding duplication (Acharya, Lima, \& Moore, 2006). If some of the actors that become involved in a development project are local to the project sites, the existing evidence suggests that this will improve project performance (Isham et al., 1995).

On the other hand, expanding the set of actors that are involved in designing and implementing a single development project can raise challenges that might prevent that development project from meeting with success.

First, additional actors imply more transaction costs. Project resources that could be spent on concrete outputs may instead be lost to mundane administrative tasks because of the increased need for meetings and reporting. As Knack and Rahman (2007), drawing on the observations of Van de Walle and Johnston (1996), describe, donors like to send expert missions, and those missions like to meet with key government officials and obtain comments for their reports. And different donors may want information provided in specific formats. Citing a World Bank press release, Knack and Rahman (2007) refer to a survey in Bolivia sponsored by five different donors, each of which had specific financial and technical reporting, "leading the government official assigned to the project to spend nearly as much of her time meeting these requirements as in undertaking the actual survey" (p. 178).

The friction association with increased transaction costs may lead to suboptimal design or implementation decisions. For instance, if multiple principals need to sign off on changes to the project during implementation, this likely means that project implementation will be less flexible and less responsive to changing conditions on the ground, mirroring the problems that Honig (2018, in press) identifies when the headquarters office of aid agencies exerts too much control.

Second, a project that is reliant on funding from multiple sources is more likely to encounter project delays. A review of World Bank Implementation Completion and Results Reports reveals that funding committed by government entities in aid-receiving countries often does not arrive, delaying project implementation and creating new transaction costs related to reallocating budgets or finding substitute financing (Winters, 2014). Entire project components may be dropped if one of the project funders proves unable to provide financing, and this may have knock-on effects for other project components that were supposed to build on the now-eliminated one. Once again, end-of-project reviews make clear that the delay or absence of counterpart funds is often blamed for project shortcomings (Winters, 2014).

Third, having multiple actors involved in development project implementation may reduce the clarity of 
the lines of accountability within the project. It can become less clear to whom contractors and subcontractors are responsible and to whom project beneficiaries should report a concern about project implementation. If different project beneficiaries identify different actors as being in charge of the project, this may lead to reports of problems or other information not being aggregated in such a way that project principals can take action. The literature already identifies a "broken feedback loop" (Martens, 2002; see also Winters, 2010) in which project beneficiaries face great challenges in making their voices heard by aid donors; having multiple donors at play in a project may exacerbate this issue.

At the macro-level, the problems of having many donors operating in a single aid-receiving country have been studied in the literature on aid fragmentation, which typically associates more donors in a country with less positive economic or institutional outcomes (e.g., Djankov, Montalvo, \& Reynal-Querol, 2009; Kimura, Mori, \& Sawada, 2012; Knack \& Rahman, 2007). Some of the most recent literature in this field suggests that more donors are not necessarily problematic for macrolevel outcomes-a finding that may carry over to the current project-level study. Ziaja (in press), for instance, argues that fragmented democracy aid can be useful for the institutionalization of democracy because it presents a "marketplace of ideas" from which the aid-receiving country can draw. As compared to the argument above about multiple principals leading to friction that drives suboptimal decisions, this framework would suggest that more entities involved in an aid project may bring more ideas that can help increase the efficiency of the project. Gehring, Michaelowa, Dreher and Spörri (2017) argue that donor fragmentation will be less problematic to the extent that donors are willing to coordinate. At the project level, if there is substantial coordination, there is the possibility of minimizing transaction costs, delays, and unclear accountability chains.

\section{Research Design}

To study how complexity in project financing relates to project outcome ratings, I combine together information about financing in World Bank projects with projectspecific outcome ratings. I use simple linear models and build on existing analyses in the literature. In the absence of an instrument predicting exogenous variation in the complexity of project financing, my findings should be understood as correlational and preliminary.

By "World Bank project," I refer to investment projects financed by the World Bank's two main lending arms, the International Bank for Reconstruction and Development (IBRD), which lends at near-market rates to middle-income countries, and the International Development Association (IDA), which provides concessional loans or grants to the world's poorest countries. In a small number of cases-known as "blend" projects-the financing comes from both the IBRD and the IDA. As de- velopment policy lending (formerly known as structural adjustment lending) does not include cofinancing, that type of World Bank lending is not included in the analysis.

World Bank projects are designed by World Bank staff in collaboration with officials from the borrowing country. Unlike some other forms of foreign assistance, where the funding is provided to non-state actors-i.e., "bypass aid" (Dietrich, 2013)-World Bank assistance flows directly to the member governments that borrow from the Bank. Where there is cofinancing from other donors, it is likely that those other donors also have been involved in the design of the project. On the other hand, as detailed in Winters and Streitfeld (2018), cofinancing from withincountry sources may be something that the government agrees to secure without actually incorporating the cofinancing entity into conversations about project design.

\subsection{Operationalizing Development Project Funding Complexity}

In order to study the extent to which having more principals involved in a development project correlates with project success or failure, I use data from Winters and Streitfeld's (2018) study of counterpart funding in World Bank projects. This data describes the number of entities making financial commitments to particular World Bank projects at the time of project approval.

The data in Winters and Streitfeld (2018) was collected in two waves from the World Bank Projects Database. Originally, the authors hand-coded the financing in 2,631 World Bank (IBRD/IDA) investment projects that were approved in the 2000-2010 period using the financing tables found in the Project Appraisal Document (PAD) or other publicly available documents. Later, the authors webscraped the "financing tab" of the World Bank Projects Database for 1,676 projects listed as having been approved during the 2011-2017 period.

The authors then recoded the funding information into a set of 13 categories reflecting different withinborrower entities and a set of 32 codes reflecting either specific (e.g., "United Kingdom") or generic (e.g., "Unidentified Bilteral Donors") international sources. In doing so, the authors collapsed together some information. Specifically, for the international codes, funding from any of the World Bank-administered trust funds was included in a general trust fund category; funding from the regional development banks was included in a generic regional fund category; and funding from other multilateral lenders was included in a generic multilateral donor category. In some cases, it may be possible that the collapsing of information has led to multiple funders being combined together in a single category. There also are generic local and international categories for cases where the documentation did not precisely identify the source of financing. The finance coding categories are listed in Table 1.

I use this underlying data to create a series of explanatory variables meant to proxy for project complexity in 
Table 1. Coding categories for funding in World Bank projects.

\section{Domestic Financing Categories}

\section{Borrower}

\section{Borrowing Agency}

Borrowing Country's Financial Intermediaries

Local Governments of Borrowing Country

Municipalities of Borrowing Country

NGOs of Borrowing Country

Local Beneficiaries
Local Communities

Local Farmer Organizations

(Unidentified) Local Sources of Borrowing Country

Private Sector

Sub-Borrowers

(Unidentified) Others

\section{International Financers}

Australia
Austria
Belgium
(Unidentified) Bilateral Donor(s)
Canada
Denmark
European Union
Finland
France
Germany
Ireland
Italy
Japan
Korea
Kuwait
Multilateral Fund

The Netherlands

New Zealand

Norway

Private Sources

Regional Fund

Russia

Saudi Arabia

South Africa

Spain

St. Kitts and Nevis

Sweden

Switzerland

Trust Fund

Unidentified International Source

United Kingdom

United States

Note: Categories are developed in Winters and Streitfeld (2018).

terms of the number of different principals involved in project design and implementation. First, I create a series of indicator variables for whether there was cofinancing from (1) any government entity on the borrower side, (2) any community-level entity on the borrower side, (3) any non-government organization in the borrower country, and (4) any foreign donor besides the World Bank. Second, I create a variable that counts the number of nonWorld Bank sources of financing in each project. In the data, 13 percent of projects feature only World Bank funding; 51 percent involve funding from the World Bank and one other source; and 36 percent involve funding from two or more sources in addition to the World Bank. Third, I create a Hirschman-Herfindahl concentration index in which I sum the squared financing shares of all categories of entities contributing to the project. Higher values of this variable indicate that a small number of financing entities provide the majority of project financing; when all funding comes from the World Bank, this index takes the value 1 .

\subsection{Measuring Project Success}

As with a number of previous studies of project-level aid effectiveness, I take the outcome variable from the World Bank Internal Evaluation Group's Project Performance Ratings dataset (World Bank, 2011). I down- loaded the version of the data dated 26 July $2018^{1}$. This data includes ratings from World Bank project assessments conducted by the Independent Evaluation Group (IEG) and is described in Independent Evaluation Group (2015). In line with previous studies, I use the "overall project outcome" variable from the dataset for my outcome variable.

I use the most recent assessment available in the data. For most projects, this is the overall project outcome rating found in IEG's review of the Implementation Completion Results (ICR) report submitted by the project team to IEG. Note that this document, known as either an Evaluation Summary or an ICR Review, is prepared by IEG staff based on the review of the project previously completed by operational staff. In an ICR Review, IEG staff base their review of the project on the criteria stated in the ICR, and they have the ability to overrule the rating provided by the operational staff in the ICR.

In addition to ICR Reviews, IEG undertakes in-depth, field-based project reviews for a small subset of projects, releasing a Project Performance Assessment Report (PPAR) based on original data collection about project performance. For 10 percent of the cases in the data, the PPAR rating supersedes the ICR Review rating.

The ratings are on a six-point scale: highly unsatisfactory, unsatisfactory, moderately unsatisfactory, moderately satisfactory, satisfactory, and highly satisfactory.

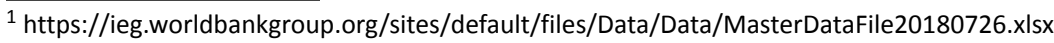


The modal category in the data is moderately satisfactory (44 percent of projects). Slightly more than one-in-four projects (28 percent) is given one of the three unsatisfactory ratings with more than half of those being the mildest of the three. The highly satisfactory rating is reserved for only a few projects ( 2.2 percent). Because of the limited use of the extreme categories on the six-point scale, I also study an indicator variable that distinguishes between projects receiving any one of the three satisfactory ratings and projects receiving any one of the three unsatisfactory ratings.

I present summary statistics for both the outcome and explanatory variable in Table 2.

\subsection{Specification}

I use a linear model to study the relationship between the measures of project complexity and the project outcome ratings. Although I lack a source of exogenous variation in financing complexity that would help identify the causal effects of having more financing entities involved in a project, I control for some potential confounding variables. I control for the total project size to avoid introducing a potential spurious correlation in which larger projects are both more likely to involve more funding entities and more or less likely to be rated as satisfactory. I also control for sector fixed effects for similar reasons (i.e., that projects in certain sectors may be more or less likely to involve multiple actors and more or less likely to be rated as satisfactory). I include fixed effects for the year of the evaluation to account for changing standards within IEG over time that may also vary with temporal trends in the prevalence of cofinancing. I include indicator variables for whether the project funding comes from the IBRD, the IDA, or both (with IDA, the modal category in the data being the omitted category) in case there is a propensity for greater cofinancing in one branch of the Bank or the other and also a propensity for differential kinds of evaluations. The data include projects financed under eight different World Bank financing mechanisms: Adaptable Program Loans, Emergency Recovery Loans, Financial Intermediary Loans, Investment Project Financing, Learning and Innovation Loans, Sector Investment and Maintenance Loans, Specific Investment Loans, and Technical Assistance Loans. Once again, given the possibility of variation in the likelihood of cofinancers and variation in the baseline likelihood of a satisfactory project across types of financing, I include a set of lending instrument fixed effects. I include an indicator variable for the type of evaluation on the grounds that PPARs may be more likely for more complex projects and also more likely to return harsher project ratings. Finally, and perhaps most importantly, I include country fixed effects to account for the possibility that certain countries may be more likely to have projects involving more or fewer partners and (for plausibly distinct reasons) may be more or less likely to have successful or unsuccessful projects. The point estimates on the project-level variables of interest are therefore based on within-country, withinyear, within-sector, and within-lending-instrument variation in project complexity and project outcomes. I cluster the standard errors on country.

\section{Results}

Table 3 presents the results. Columns (1) through (4) use the six-point evaluation ratings scale as the outcome and columns (5) through (8) use the dichotomized outcome variable. According to the results in columns (1) and (5), the within-country variation in whether or not World Bank projects involve cofinancing is such that the presence of any non-World Bank funding in a project negatively predicts project outcome ratings. The effect sizes, however, are modest. The presence of cofinancing reduces the project rating only by 0.16 points on the sixpoint scale or, alternatively, the likelihood of the project being rated satisfactory falls by seven percentage points (against a baseline likelihood of 72 percent that a project will have a satisfactory rating).

In columns (2) and (6), I break down the presence of cofinancing by including a set of indicator variables for the different types of actors that might provide funding to the project: any government entity from the borrowing country, any local-level entity, any domestic NGO, and any other external donors. In column (2), the involvement of local government entities in financing the

Table 2. Summary statistics.

\begin{tabular}{llllll}
\hline & N & Mean & SD & Min & Max \\
\hline IEG Rating (Six-Point Scale) & 2024 & 3.91 & 1.01 & 1 & 6 \\
IEG Rating (0/1) & 2024 & 0.72 & 0.45 & 0 & 1 \\
Cofinancing (0/1) & 2024 & 0.87 & 0.33 & 0 & 1 \\
Borrower Gov't (0/1) & 2024 & 0.83 & 0.38 & 0 & 1 \\
Community/Local (0/1) & 2024 & 0.12 & 0.33 & 0 & 1 \\
Domestic NGO (0/1) & 2024 & 0.00 & 0.07 & 0 & 1 \\
Other Donors (0/1) & 2024 & 0.29 & 0.46 & 0 & 0 \\
Count of Cofinancers & 2024 & 1.48 & 1.14 & 0.14 & 8 \\
Concentration of Financing & 2024 & 0.67 & 1.43 & 0.26 & 1 \\
Log (Project Size) & 2024 & 4.00 & & & 10.20 \\
\hline
\end{tabular}


Table 3. Effect of project funding complexity on development project outcomes.

\begin{tabular}{|c|c|c|c|c|c|c|c|c|}
\hline \multirow[b]{2}{*}{ Outcome: } & (1) & (2) & (3) & (4) & (5) & (6) & (7) & (8) \\
\hline & \multicolumn{4}{|c|}{ Six-Point Satisfaction Scale } & \multicolumn{4}{|c|}{ Satisfactory/Unsatisfactory } \\
\hline Any Cofinancing $(0 / 1)$ & $\begin{array}{c}-0.16^{* *} \\
(0.08)\end{array}$ & & & & $\begin{array}{c}-0.07^{*} \\
(0.04)\end{array}$ & & & \\
\hline Borrower Gov't (0/1) & & $\begin{array}{c}-0.11 \\
(0.08)\end{array}$ & & & & $\begin{array}{c}-0.04 \\
(0.04)\end{array}$ & & \\
\hline Community/Local (0/1) & & $\begin{array}{l}0.14^{* *} \\
(0.07)\end{array}$ & & & & $\begin{array}{c}0.05 \\
(0.04)\end{array}$ & & \\
\hline Domestic NGO (0/1) & & $\begin{array}{c}-0.51 \\
(0.33)\end{array}$ & & & & $\begin{array}{c}-0.43^{* *} \\
(0.18)\end{array}$ & & \\
\hline Other Donors $(0 / 1)$ & & $\begin{array}{c}-0.04 \\
(0.05)\end{array}$ & & & & $\begin{array}{c}-0.01 \\
(0.02)\end{array}$ & & \\
\hline Count of Cofinancers & & & $\begin{array}{c}-0.00 \\
(0.02)\end{array}$ & & & & $\begin{array}{c}-0.01 \\
(0.01)\end{array}$ & \\
\hline Concentration of Financing & & & & $\begin{array}{c}0.23 \\
(0.14)\end{array}$ & & & & $\begin{array}{c}0.15^{* *} \\
(0.06)\end{array}$ \\
\hline Log(Project Size) & $\begin{array}{l}0.10^{* * *} \\
(0.02)\end{array}$ & $\begin{array}{l}0.10^{* * *} \\
(0.02)\end{array}$ & $\begin{array}{l}0.09 * * * \\
(0.02)\end{array}$ & $\begin{array}{l}0.10 * * * \\
(0.02)\end{array}$ & $\begin{array}{l}0.05^{* * *} \\
(0.01)\end{array}$ & $\begin{array}{l}0.05^{* * *} \\
(0.01)\end{array}$ & $\begin{array}{l}0.05^{* * *} \\
(0.01)\end{array}$ & $\begin{array}{l}0.05^{* * *} \\
(0.01)\end{array}$ \\
\hline Observations & 2,024 & 2,024 & 2,024 & 2,024 & 2,024 & 2,024 & 2,024 & 2,024 \\
\hline Adjusted $\mathrm{R}^{2}$ & 0.12 & 0.12 & 0.12 & 0.12 & 0.06 & 0.07 & 0.06 & 0.07 \\
\hline
\end{tabular}

Notes: All models are linear regression models that include indicators for IBRD and blend funding, an indicator for PPAR ratings, and country, year, sector, and lending instrument fixed effects. Robust standard errors clustered on country in parentheses. ${ }^{*} p<0.10$; ** $\mathrm{p}<0.05$; *** $\mathrm{p}<0.01$.

project correlates with worse performance ratings (although not significantly so), whereas the presence of funding from community organizations correlates with better performance ratings, conditional on the other variables in the model. The signs of these variables remain consistent in column (6), but the uncertainty in their estimation increases. There is a large and negative coefficient in column (2) on the indicator for the presence of funding from a domestic NGO in the project; in column (6), with the dichotomized outcome, this effect becomes statistically significant at conventional levels. According to column (6), the presence of funding from a domestic NGO decreases the probability of a project getting a satisfactory rating by a striking 43 percentage points. There are only 10 projects in all of the data, however, where domestic NGOs provide funding. Given the numerous fixed effects in the model, this estimate may be based on the performance of an even smaller number of projects. The presence of foreign donors other than the World Bank does not significantly correlate with project performance in either column (2) or column (6); this variable produces coefficient estimates close to zero. Removing the indicators other than for the borrower government from the model and comparing those projects with borrower government involvement to all other projects produces coefficient estimates that are approximately the same magnitude and significance as those in Table 3 (results not reported).

In columns (3) and (7), the coefficient on the raw count of the number of actors providing funding to the project is negative but small in magnitude and not sta- tistically significant. In columns (4) and (8), on the other hand, the concentration of project funding as measured by the Hirschman-Herfindahl Index is a positive predictor of project success (and a statistically significant one for the dichotomous outcome): where project funding is more concentrated, we can expect to see more satisfactory project outcomes. This variable ranges from 0.14 to 1.0 with a standard deviation of 0.2 . The substantive effect of a one standard deviation change in the concentration of funding is therefore relatively small: a one standard deviation increase in the concentration of funding correlates only with a 0.05 point increase on the sixpoint satisfaction scale or a 3.0 percentage point increase in the probability of any kind of satisfactory rating, conditional on the other variables in the model. Although small, the result is consistent with the result presented in columns (1) and (5) that overall project ratings are lower, ceteris paribus, in the presence of cofinancing.

In all of the regressions reported in Table 3, total project size is a positive predictor of the project ratings. Denizer et al. (2013) find the opposite result, that larger projects receive less positive ratings, whereas Shin et al. (2017) report a similar finding as here, that larger projects are more highly rated. Denizer et al. (2013) study a much larger set of projects, going further back in history, whereas Shin et al. (2017) study projects from a time period similar to the one studied here. Therefore, this may be an association that has changed over time. Looking only at the bivariate correlation between log total project size and the IEG rating, the correlation is positive and highly significant. 
For some of the indicator variables used in Table 3, some of the categories indicating the presence or absence of a particular type of actor mask the fact that multiple entities from that category were involved in the project. For instance, of the 1,688 projects in the data involving a domestic government actor, 79 of those involve multiple government actors. Likewise, of the 553 projects that involve financing from other foreign donors, 129 involve financing from two other donors; 49 involve financing from three other donors; and 30 involve financing from four other donors. In Table 4, therefore, I replace the $0 / 1$ indicators for these types of financing with count variables for the number of financing entities under each of these categories. Column (1) uses the sixpoint scale as the outcome, while column (2) uses the satisfactory/unsatisfactory distinction.

The results in Table 4 largely follow those in Table 3. Using the six-point scale, we see a marginally significant positive correlation between community funding and project success; although we see a negative correlation between the count of domestic government agencies contributing to the project and the project outcome, it is not statistically significant (as compared to the binary predictor in column (1) of Table 3 ). Using the dichotomous satisfactory versus unsatisfactory outcome, the presence of a domestic NGO remains a large and significant negative predictor of project success, and none of the other funding source variables are significant.

\subsection{Project Delay Mechanism}

As described above, cofinancing frequently is delayed, and project evaluations frequently complain about this delay in cofinancing and attribute problems in the project to the delay. Although it is challenging to find proxies for the transaction cost mechanism or the accountability mechanism described above, I can look for evidence of the project delay mechanism by studying the relationship between cofinancing and project length.

In column (1) of Table 5, I regress project duration (closing date minus approval date) on cofinancing, total project size, and the set of indicator variables for country, year, and project characteristics included in the main specification above. The results show that cofinancing

Table 4. Effect of project funding complexity on development project outcomes (additional count variables).

\begin{tabular}{|c|c|c|}
\hline Outcome & $\begin{array}{c}(1) \\
\text { Six-Point Satisfaction Scale }\end{array}$ & $\begin{array}{c}(2) \\
\text { Satisfactory/Unsatisfactory }\end{array}$ \\
\hline Count of Borrower Government & $\begin{array}{l}-0.05 \\
(0.07)\end{array}$ & $\begin{array}{r}-0.01 \\
(0.03)\end{array}$ \\
\hline Community/Local (0/1) & $\begin{array}{l}0.14^{* *} \\
(0.07)\end{array}$ & $\begin{array}{c}0.05 \\
(0.04)\end{array}$ \\
\hline Domestic NGO (0/1) & $\begin{array}{c}-0.51 \\
(0.34)\end{array}$ & $\begin{array}{l}-0.42 * * \\
(0.18)\end{array}$ \\
\hline Count of Other Donors & $\begin{array}{c}-0.03 \\
(0.03)\end{array}$ & $\begin{array}{c}-0.01 \\
(0.01)\end{array}$ \\
\hline Log (Project Size) & $\begin{array}{l}0.10^{* * *} \\
(0.02)\end{array}$ & $\begin{array}{l}0.05^{* * *} \\
(0.01)\end{array}$ \\
\hline Observations & 2,024 & 2,024 \\
\hline Adjusted $\mathrm{R}^{2}$ & 0.12 & 0.06 \\
\hline
\end{tabular}

Notes: All models are linear regression models that include indicators for IBRD and blend funding, an indicator for PPAR ratings, and country, year, sector, and lending instrument fixed effects. ${ }^{*} p<0.10 ; * * p<0.05 ; * * *<0.01$.

Table 5. Project funding complexity, project duration, and project ratings.

(1)

Outcome

Any Cofinancing (0/1) Project Duration (Years)

$1.35^{* * *}$

Project Duration (Years)

Log (Project Size)

Observations

0.22
(2) Six-Point Satisfaction Scale

2,019

0.11

Notes: both models are linear regression models that include indicators for IBRD and blend funding, an indicator for PPAR ratings, and country, year, sector, and lending instrument fixed effects. ${ }^{*} p<0.10 ; * *<0.05 ; * * p<0.01$. 
clearly leads to project delays. Controlling for project size, the presence of cofinancing is associated with an increased project duration of 1.35 years.

Longer projects, however, do not imply worse ratings. Column (2) shows that the measure of project duration is not significantly associated with project outcome ratings when we add it to the specification from column (1) of Table 3. The coefficient on cofinancing is of the same magnitude as above and remains statistically significant. Therefore, insofar as we are finding evidence that cofinancing negatively affects project ratings, the pathway does not seem to be through simply extending the duration of a project.

\subsection{Additional Analyses}

As described above, the main estimating equation controls for various project characteristics, such as the arm of the World Bank providing the lending and the specific category of loan. In addition, the evaluation data comes from two types of evaluations: the more superficial ICR Reviews and the field-based PPARs. In Table 6, I use these project and evaluation characteristics to subset the data and study the correlation between cofinancing and project ratings across various types of projects.

Columns (1) and (2) look at projects where the World Bank funding included in the project comes from either the IBRD or the IDA. ("Blend" projects that include funding from both are not reported because of their small number.) In both IBRD and IDA projects, the presence of cofinancing negatively correlates with project ratings, conditional on the other variables included in the model. The relationship is only statistically significant for IDA projects, but the two coefficients are not statistically distinguishable.

In column (3), I look only at specific investment projects. For these projects, the negative relationship between cofinancing and project ratings is reduced in magnitude and does not achieve conventional levels of statistical significance. Conversely, across the remaining types of World Bank lending, the relationship is larger and estimated more precisely than the overall relationship re- ported in Table 3. Column (6) suggests that cofinancing may be particularly deleterious in Emergency Recovery Loans: the coefficient indicates that the presence of cofinancing in these loans is associated with a project rating that is over half a point less than those found in otherwise similar Emergency Recovery Loans without cofinancing. The estimate in column (7) is far from statistical significance, but it provides some evidence that Technical Assistance Loans might receive higher project ratings when there is cofinancing. This would make sense, as government cofinancing might truly be a sign of government buy-in in these projects.

Columns (8) and (9) look to see if the results change when we subset the data to only the desk-based ICR Reviews or the field-based PPARs. The coefficients are indistinguishable, although given the relatively smaller number of PPARs, there is much more uncertainty in the estimate when we only use projects with that kind of evaluation.

Overall, these results reinforce the patterns identified in Table 3, although they suggest that problems brought about by cofinancing might be particularly deleterious in Emergency Recovery Loans and that cofinancing might actually be beneficial in Technical Assistance Loans.

\section{Conclusions}

I study whether or not multiple financing sources in World Bank projects are associated with undesirable project outcomes, combining data on project cofinancing with the IEG Project Ratings Database that has been used in previous work. I hypothesize that a diversity of funding flows may correlate with less satisfactory project performance because of friction associated with increased transaction costs, the possibility of delayed implementation, and the issue of blurred lines of accountability. Overall, I find indications in favor of the theory: World Bank projects with any cofinancing and with less concentrated financing receive less positive evaluations. The estimated correlations, however, are generally small in size, conditioning on other project characteristics and using country and year fixed effects.

Table 6. Project complexity and project ratings within subsets of projects.

\begin{tabular}{|c|c|c|c|c|c|c|c|c|c|}
\hline Subset & $\begin{array}{c}\text { (1) } \\
\text { IBRD } \\
\text { Projects }\end{array}$ & $\begin{array}{c}\text { (2) } \\
\text { IDA } \\
\text { Projects }\end{array}$ & $\begin{array}{c}\text { (3) } \\
\text { Specific } \\
\text { Investment } \\
\text { Loans }\end{array}$ & $\begin{array}{c}\text { (4) } \\
\text { All Other } \\
\text { Types of } \\
\text { Loans }\end{array}$ & $\begin{array}{c}\text { (5) } \\
\text { Adaptable } \\
\text { Program } \\
\text { Loans }\end{array}$ & $\begin{array}{c}(6) \\
\text { Emergency } \\
\text { Recovery } \\
\text { Loans }\end{array}$ & $\begin{array}{c}\text { (7) } \\
\text { Technical } \\
\text { Assistance } \\
\text { Loans }\end{array}$ & ICRRs & PARs \\
\hline Any Cof. & -0.20 & $-0.17^{*}$ & -0.12 & $-0.29 * * *$ & -0.15 & $-0.64 * *$ & 0.28 & $-0.19 * *$ & -0.19 \\
\hline$(0 / 1)$ & $(0.23)$ & (0.09) & $(0.12)$ & $(0.11)$ & $(0.28)$ & $(0.31)$ & $(0.56)$ & $(0.08)$ & $(0.55)$ \\
\hline $\mathrm{N}$ & 734 & 1,236 & 1,244 & 780 & 302 & 154 & 179 & 1,828 & 196 \\
\hline Adj. $R^{2}$ & 0.28 & 0.20 & 0.25 & 0.25 & 0.45 & 0.75 & 0.60 & 0.21 & 0.51 \\
\hline
\end{tabular}

Notes: all models are linear regression models that include log(total project size) and country, year, and sector fixed effects. Columns (1) and (2) include an indicator for PPAR ratings and lending instrument fixed effects. Columns (3) through (7) include indicators for IBRD and blend funding and an indicator for PPAR ratings. Columns (8) and (9) include indicators for IBRD and blend funding and lending instrument fixed effects. $* \mathrm{p}<0.10 ;{ }^{* *} \mathrm{p}<0.05 ;{ }^{* * *} \mathrm{p}<0.01$. 
When I try to identify if cofinancing streams from specific types of partners are particularly problematic, I find some evidence that local-level participation may lead to better project performance, a result that is in line with the existing literature (Isham et al., 1995). The partial correlation, however, is estimated with a fair amount of uncertainty, depending on the outcome variable, and is small in magnitude.

When local NGOs provide financing, however, I identify a large, negative correlation with project satisfaction ratings, which is significant for one of the two outcome measures. This finding contrasts with Shin et al.'s (2017) finding that World Bank projects with non-government implementers receive higher project ratings than those that are implemented by a government agency. In both that article and this one, the number of observations that include NGO involvement is small, such that it may be the case that a few good or bad projects drive the results. I was not able to obtain replication data from the Shin et al. (2017) article to explore the overlap in the projects that we are studying or our coding of NGO participation. While I look at whether or not domestic NGOs make a financial contribution to the project, they ostensibly identify World Bank-funded projects that are implemented by NGOs.

The study of project-level outcomes remains crucial for the overall study of aid effectiveness. Whereas overall aid flows result from a variety of geopolitical and domestic political processes-giving developmentoriented practitioners less control, project-level design decisions are typically made by bureaucratic agents with sincere interests in development (Iannantuoni, Waeiss, \& Winters, 2018; Winters \& Streitfeld, 2018). Continuing to build up our knowledge about which project design elements facilitate development impact is an important endeavor for concretely making aid more effective.

\section{Acknowledgments}

Thanks to Miles Williams for excellent research assistance. Thanks to Jaclyn Streitfeld for all of her input in designing and implementing the counterpart funding coding scheme.

\section{Conflict of Interests}

The author declares no conflict of interests.

\section{References}

Acharya, A., de Lima, A., \& Moore, M. (2006). Proliferation and fragmentation: Transactions costs and the value of aid. Journal of Development Studies, 42(1), 1-21. https://doi.org/10.1080/00220380500356225

Deininger, K., Squire, L., \& Basu, S. (1998). Does economic analysis improve the quality of foreign assistance? The World Bank Economic Review, 12(3), 385-418. https://doi.org/10.1093/wber/12.3.385
Denizer, C., Kaufmann, D., \& Kraay, A. (2013). Good countries or good projects? Macro and micro correlates of World Bank project performance. Journal of Development Economics, 105, 288-302.

Dietrich, S. (2013). Bypass or engage? Explaining donor delivery tactics in foreign aid allocation. International Studies Quarterly, 57(4), 698-712. https://doi.org/ 10.1111/isqu.12041

Djankov, S., Montalvo, J. G., \& Reynal-Querol, M. (2009). Aid with multiple personalities. Journal of Comparative Economics, 37(2), 217-229. https://doi.org/10. 1016/j.jce.2008.09.005

Dollar, D., \& Levin, V. (2005). Sowing and reaping: Institutional quality and project outcomes in developing countries (World Bank policy research working paper, 3524). https://doi.org/10.1596/1813-9450-3524

Finsterbusch, K., \& Van Wicklin, W. A. (1987). The contribution of beneficiary participation to development project effectiveness. Public Administration and Development, 7(1), 1-23. https://doi.org/10.1002/pad. 4230070102

Gehring, K., Michaelowa, K., Dreher, A., \& Spörri, F. (2017). Aid fragmentation and effectiveness: What do we really know? World Development, 99, 320-334. https://doi.org/10.1016/j.worlddev.2017.05.019

Guillaumont, P., \& Laajaj, R. (2006). When instability increases the effectiveness of aid projects (World Bank policy research working paper, 4034). https://doi. org/10.1596/1813-9450-4034

Honig, D. (2018). Navigation by judgment: Why and when top down management of foreign aid doesn't work. New York, NY: Oxford University Press.

Honig, D. (in press). When reporting undermines performance: The costs of politically constrained organizational autonomy in foreign aid implementation. International Organization. https://doi.org/10.1017/ S002081831800036X

Iannantuoni, A., Waeiss, C., \& Winters, M. S. (2018). Dayto-day decisions of egalitarian and non-egalitarian international organizations: Evidence from the Global Environment Facility. Manuscript submitted for publication.

Independent Evaluation Group. (2015). World Bank project performance ratings-Codebook. Retrieved from https://ieg.worldbankgroup.org/sites/default/ files/Data/reports/ieg-wb-project-performanceratings-codebook_092015.pdf

Isham, J., \& Kaufmann, D. (1999). The forgotten rationale for policy reform: The productivity of investment projects. Quarterly Journal of Economics, 114(1), 149-184.

Isham, J., Kaufmann, D., \& Pritchett, L. H. (1997). Civil liberties, democracy, and the performance of government projects. World Bank Economic Review, 11(2), 219-242. https://doi.org/10.1093/wber/11.2.219

Isham, J., Narayan, D., \& Pritchett, L. (1995). Does participation improve performance? Establishing causality with subjective data. World Bank Economic Review, 
9(2), 17-200.

Kilby, C. (2000). Supervision and performance: The case of World Bank projects. Journal of Development Economics, 62(1), 233-259.

Kilby, C. (2015). Assessing the impact of World Bank preparation on project outcomes. Journal of Development Economics, 115, 111-123. https://doi.org/ 10.1016/j.jdeveco.2015.02.005

Kimura, H., Mori, Y., \& Sawada, Y. (2012). Aid proliferation and economic growth: A cross-country analysis. World Development, 40(1), 1-10. https://doi.org/ 10.1016/j.worlddev.2011.05.010

Knack, S., \& Rahman, A. (2007). Donor fragmentation and bureaucratic quality in aid recipients. Journal of Development Economics, 83(1), 176-197.

Martens, B. (2002). Introduction. In B. Martens, U. Mummert, P. Murrell, \& P. Seabright (Eds.), The institutional economics of foreign aid. New York, NY: Cambridge University Press.

Qian, N. (2015). Making progress on foreign aid. Annual Review of Economics, 7(1), 277-308. https://doi.org/ 10.1146/annurev-economics-080614-115553

Shin, W., Kim, Y., \& Sohn, H.-S. (2017). Do different implementing partnerships lead to different project outcomes? Evidence from the World Bank project-level evaluation data. World Development, 95, 268-284. https://doi.org/10.1016/j.worlddev.2017.02.033

Van de Walle, N., \& Johnston, T. (1996). Improving aid to Africa. Washington, DC: Overseas Development Council.

World Bank. (2011). IEG World Bank project performance ratings. World Bank Group. Retrieved from https://datacatalog.worldbank.org/dataset/iegworld-bank-project-performance-ratings

Winters, M. S. (2010). Accountability, participation and foreign aid effectiveness. International Studies Review, 12(2), 218-243. https://doi.org/10.1111/j. 1468-2486.2010.00929.x

Winters, M. S. (2014). Targeting, accountability and capture in development projects. International Studies Quarterly, 58(2), 393-404. https://doi.org/10.1111/ isqu. 12075

Winters, M. S., \& Streitfeld, J. D. (2018). Splitting the check: Explaining patterns of counterpart commitments in World Bank projects. Review of International Political Economy, 25(6), 884-908. https://doi. org/10.1080/09692290.2018.1490328

Ziaja, S. (in press). More donors, more democracy. Journal of Politics. Retrieved from http://www.ziaja. koeln/d/Ziaja\%202018\%20More\%20donors,\%20 more\%20democracy\%20-\%20accepted\%20in\%20 JoP.pdf

\section{About the Author}

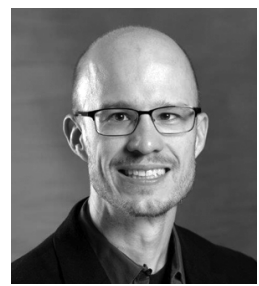

Matthew S. Winters is Associate Professor and Associate Head for Graduate Programs in the Department of Political Science at the University of Illinois. His research interests include the allocation and effectiveness of foreign aid, the political-economy of governance, and voter attitudes toward corruption. He has published articles in Journal of Politics, Comparative Politics, International Studies Quarterly, World Development, and World Politics, among other outlets, and has worked as a consultant for USAID, AusAID, and the World Bank's Independent Evaluations Group. 